\title{
Kunst, tid og rum
}

Mario Perniola

Kunst og „tidsånd"

Det er svært at modstå fristelsen til at definere kunstens aktuelle status med begrebet neo-eklekticisme“. Faktisk synes ethvert enhedsligt princip. som man kan henføre kunstens forskellige udtryksmåder til, at have opløst sig, og den historiske proces synes at have mistet enhver præcis retning, sel den mest foreløbige og forbigående. Begrebet „neoeklekticisme" kan derfor dække en situation af desorientering og ubestemthed, som viser sig i den forvirrede tilbagevenden af fortidens stilarter (ikke én ad gangen, men alle sammen samtidig), der fratage enhver historisk nødvendighed mere ligner måder, man kan tage eller lade ligge alt efter personligt forgodtbefindende, end det ligner sammenteng formelle enheder. Det viser sig så i udængende af de teoretisk. Det vistomninge af te teor iske persper den blev abnet op for, og af selve avantgardebegre bet forstâet som en kategorisk og entydig angivels af en kollektiv søgen, der skulle foregribe historien gang.

Denne opløsning af poetiske og kritiske vishede rammer ikke kun forestillingerne om stilarter og on avantgarden, men også om revival og mode. Tendenserne til retro og moderne, der har afløst hinanden på en stadig mere forpustet måde, forudsatte dog altid eksistensen af en tidslig dimension, der lod sig ordne diakront. Og uanset hvilke forskelle man i ovrigt vil satte mellem stil og retro, mellem avantgarde og mode, har de alle indeholdt en henving til samfundets , har de alle indelenten henvisning proces Det fak a proce Det halvt àrhundrede orden kan når man prøver at se på forudsætningerne for på en faring. Men andre forhold gør det nødvendigt at tænke kunstarternes nuværende tilstand som neoeklekticisme. På den ene side betyder eklekticisme såvel etymologisk som begrebsligt, at væloe med cillo henblik pa et knid, som man hævder stadigt a inærme sig re midlertid ikke blot et ideal til at bestemme kritikken. Det karakteristiske ved den nuværende situation er umuligheden af at vælge eller nærmere den perfekte ligegyldighed og reversibilitet $i$ valgene, den mangfoldighed af forslag, der ikke lader sig reducere til nogen form for enhed eller til nogen bestemt poetisk eller kritisk horisont. På den anden side er præfikset "neo“ vildledende, fordi det forleder én til at tænke et fænomen af et helt andet omfang og en helt anden radikalitet i neoavantgardens terminologi. Det, der synes uigenkaldeligt kompromitteret, er båndet mellem kunst og historie, dvs muligheden for at forfalse den vej, som Wince dvs. inckelanter

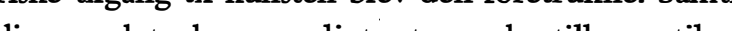
dig er det dog unuligt at vende tilbage til et metahistorisk og idealistisk syn pa kunsten, da betingelserne for at fastsætte en evig gyldighed fo denne mangler totalt. Endelig forstørrer suffikse "isme“ forvirringen og mangfoldiggør misforståel serne, fordi det antager eksistensen af en ny poetik, af en ny mere eller mindre konsekvent kunstnerisk tendens på linje med kunsthistoriens mange ,ismer", mens det først og fremmest drejer sig om en udjævning og sidestilling af alle poetikker, om erobringen af en synsvinkel man kunne kalde ,uden for slagsmålet", en synsvinkel som er mere filosofisk or organistorisk end den er programmatisk og o Der er ilke Der er ike sta iser blod kunstrene, der fortolker den ak fille siturion som en generobring a individets frie kreativitet fra de band og begrænsninger, som en social forestilling om kunsten pålagde dem. Det virker, som om Wölfflins forskrif om kunsten, at „alt er ikke muligt til alle tider", endelig er faldet, og at den har trukket enhver bistorisk-kunstnerisk norm med sig og åbnet et uendeligt felt af muligheder for den enkelte kunstner. stedet for stilarternes og avantgardernes „kunsthistorie uden navne“ ser de nu en „kunsthistorie ku af navne", hvor individet ikke mere er forpligtet pà kunstens indre rationalitet og ikke engang på en sammenhængende personlig udvikling. Det er ikke kunsten, der er deres fxngsel, men kunsthistorien med dens systematiske inddelinger og kunstorie (1) intentioner og retning.

I virkeligheden handler det dog ikke om subjektets triumf, men tværtimod om dets oplosning. De individuelle subjekt har ikke større mulighed for at forblive intakt, end det kollektive subjekt har. Avantgardegruppen forlader således ikke pladsen til fordel for geniet, men for idiosynkrasier, manier o de mest tilfæeldige, personlige tics. Ingen kan kalde sig en fortolker af sin tid, fordi tiden i en håbløs og gådefuld uafgjorthed synes at indeholde og udholde alt og det modsatte af alt. Man kan ikke længere forestille sig noget gensidigt tilhørsforhold mellem det historiske ojeblik og det individuelle subjekt, unset bror

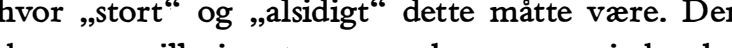
der nare inh sonen gøre alt, ophaver ham ikke til den fri skabelses timder, men forviser ham til dilettanteri og reducere dybest set kunsten til tidsfordriv. Den overdrevne og fanatiske påstand om én hel og uklassificerbar skabende originalitet, der rækker ud over tendenser og grupper, ender ikke med at lukke kunstneren inde en ensomhed, som fremtiden vil udfri ham af, me tværtimod med at drukne ham i den talrige hær a søndagsmalere eller i den uformelige sammenstimlen af foux artistiques.

Den egyptiske effekt: tidens fuldbyrdelse

Kunstens nuværende tilstand er altså hverken bestemt af en neo-eklekticisme eller af en neo-romantik, men af en mere radikal og afgørende forandring, som jeg vil definere som den „egyptiske effekt". Typisk for den egyptiske civilisation var faktisk en tendens til at ophære det antikke og det nye $i$ en enkelt tidslig dimension, at anbringe dem side om side og lade de modsigelser, der kom ud af det, stå åbne. Heraf det indtryk af gådefuld synkroni o næsten af tidens fuldbyrdelse, som de egyptiske frembringelser giver. 
I dag manifesterer denne tidens fyldthed, denne nutidens gøren sig gældende som tidens eneste dimension, sig i sammentrækningen, i identifikatione og $i$ den gensidige annullering af begreber, der indtil i går var modsætninger: aktualiteten og repertoiret det ab enbare og akjivet, udstillingen og magainet tydeligste elo og magasnet. Det tecligste ckemen gere og med det nye tilbehør til fjernsynet er det straks tilbagevendende nutiden selv, der løsrevet fr sin egen enestånde karakter hele tiden synes at være på vippen til at gentage sig umiddelbart elle at have været et øjeblik tidligere. Hvis jeg optage en direkte transmission for at se den to minutter senere, mister den fuldstændig aktualitetens udstràling, og omvendt betyder dét, at man i kraft at telematikken kan disponere over en uendelig mængde af billeder og informationer, en transformation a den rene modtagen $i$ en nutidig handling. Hvis alt kan forsinkes, er intet aktuelt og omvendt, hvis alt umiddelbart kan blive nerverende, er alt rep a

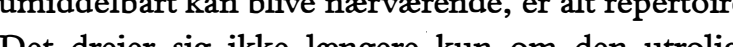
Det drejer sig ike langere hen on den sammentrakning af foriden, hvor sidste mâneds nyheder virker lige sa feme som det, der skete for 2000 år siden og oldhistorien lige så nær som begivenheder fra $i$ forgårs, men om en gådefiuld samtidighed af fortid og nutid, der på én gang udelukke muligheden for at bevise rigtigheden af det netop levede ojeblik.og for at hæve sig op til en arché, et princip, en oprindelse. Nutiden er blevet til en fortid, der straks vender tilbage, og fortiden er bleve en potentiel nutid, der til enhver tid kan gøres aktuel.

Den egyptiske effekt skyldes ikke manglen på nyheder, og den udspringer heller ikke af en realiseine og den und

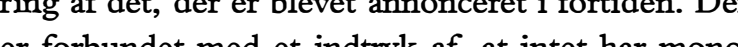
er for pol pa at gore sig til herre over tiden eller på a ale en aktuelle tid. Tiden er fuldbyrdet, fordi den ikke længere har en bestemt kunstnerisk vilje eller en forme identitet, som den er uadskillelig fra. Den fuldbyrdede tid relativerer hele det kunstneriske univers, idet den transformerer aktualiteten $i$ anledning os repertoiret $i$ inventar.
Den terroristiske trussel fra en aktualitet, der fremstår som universel gyldig, overlader pladsen til mødet mellem en lokal tid og en form frigjort totalitære krav. Kravet om én gang for alle at los den kunstreriske skabens problem formindskes, kunsten aftledes den metafysiske ubskes, (entingethed som modemed. Aktualiteil a bolle sig ajour, til at holde sig ajour, der bliver stadig mere krampagtig og uafsluttelig, er aflost af en mangfoldighed af anledninger, af tilliden til at alt kan fả sin chance, af overbevisningen om at forsinkelse og fremskyndelse er taktiske og ikke strategiske begreber. Som den egyptiske myte vil Isis altid være der til at samle Osiris' spredte lemmer.

Men hvis den fuldbyrdede tid giver muligheder til alle, betyder det ikke, at alt lykkes. Tværtimod er den fuldbyrdede tid ekstremt mere krævende og streng, fordi ingen længere kan bytte deres egen nyhed med andres overbmrenhed. Fra det ajeblik, hvor hed med andres overbarenhed. Fra det ojeblik, hvor alt thunstigt pa samme tid, er der ikke lejle lejligheden betyder ikke at bruge alting som anledning til at udtrykke sin egen subjektivitet, og sle ikke at ledsage enhver begivenhed med billige perifraser. Det betyder derimod at forbinde en tidslig og en formel dimension efter omstændigheder, der pålægges subjektet og fuldstændigt ser bort fra dettes personlige forfængelighed, idet de implicerer dere egen indre perfektion

Hvis forestilllingen om anledningen introducerer et statisk og synkront element $i$ oplevelsen af nutiden, introducerer forestillingen om inventaret $e$ dynamisk og diakront element $i$ besiddelsen af fortiden. Hvis anledningen bryder forholdet melem den aktuelle id og fom es i form, sa bry inver for ate dites organisering af materialet knuser de traspiller en egyptisk effekt ind. Faktisk er et ande fundamentalt aspekt ved de gamle egypteres mentalitet netop princippet om den fir erstattelighed og udskiftelighed: at ethvert element kan skiftes ud med et andet. Verden er et stort variabelt system hvor det høje og det lave, det maskuline og det feminine, det lyse og det mørke, livet og døden, det organiske og det uorganiske til stadighed byttes om og kombineres. Heri ligger netop den berømte gåde $i$ ars combinatoria, som generationer af forskere ha søgt i det gamle Egypten.

Når fortiden på forkellige måder kan gores til in Nar foriden pa forkellige ventar, kom en stabil for fremsta som serdeles skobe og tilfældigt. Det drejer sig ikke kun om $i$ hojere grad at brede de objekter, man interesserer sig for, ud ved at forandre historien om kunsten til historien om tingene, me også og især om at arbejde med tværgående taksonomier, der afslører affiniteter ved aspekter, de umiddelbart står hinanden fjernt, og omvendt afslorer modsætninger ved notorisk tæt relaterede aspekter. Inventaret er således knyttet til en begrebslig og organisatorisk praksis, der skærer i fortiden efter hidtil ukendte perspektiver. Det drejer sig altså om en tilgangsmåde, der står som antipode til traditionens stille kustoder. Den fuldbyrdede tid medfor nens sille kude der. Den fuldycte tid medfrer dermed absolut ilk en reging og stadfrstelse af universet, men ger det et ubegrænset antal af katalogiseringer.

Den egyptiske effekt betyder en overgang fra en europæisk æstetik af græsk oprindelse til en æstetik, der finder sine modeller $\mathrm{i}$ andre præ-klassiske og ikke-europæiske civilisationer. Dette medfører en opløsning af mange modsætninger som fx mellem original og kopi, oprindelig og uægte, funktion of ornament. Foran den svimlende mangfoldiggørelse af imitationer der ikke lader sig skelne fra originalen, foran den ekstreme variation af synkretismer som kræver en selvstændig overvejelse, foran den udspiling of forestillingen om funktion som ogs infter pog omater polition af faingen, punkter i oplosning, og desorienteringen og forvirringen vokser. Forstllngencen renhed og

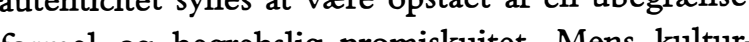
formel og begrebslig promiskuitet. Mens kultur eksporten $i$ kolonitiden forøgede oprindelseslande prestige og gav et højtideligt indtryk, skaber den $n$ uægte versioner, der vækker stonre interesse end originalerne og vidner om en allerede fraværende vitalitet i prototyperne. Alt dette kan ikke omfattes af en neo-eklektisk eller en neo-romantisk poetik, men opfordrer til en blandingens og fratagelsens æstetik, hvis formulering dog stadig synes at mangle et støttepunkt.

Faktisk synes den europæiske æstetik ikke at kunne tillade blandinger, men kun forvirringer, til trods for alle de pirringer, den lover, mangler den paradoksalt nok bade sjal og lop. Dybest set gor

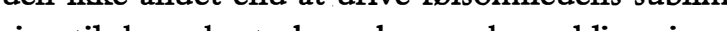
ring til den yderste konsekvens, den sublimering $p$ hvilken den i 1700-tallet skabte sin egen disciplin autonomi over konfrontationen mellem intellekte og viljen, mellem evnen til at erkende og evnen ti at begære. Det er således muligt at afdække en essentiel kontinuitet mellem 170o-tallets æstetik, der artikulerede sig på forestillingerne om følelse og smag, og nutidens superæstetik, der baserer sig på billeder, forestillinger, at alt blandes med alt, mens den i praksis realiseres ved den oplevelse af behag, som seer- og lyttertal fortæller os om.

Det, som den fuldbyrdede tid opfordrer til, er ilke en superatetik, men fart og femmert

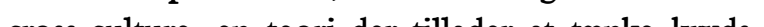
cins-cine at ig retren il me forstår at in forstar at skabe rum for sporgsmalet on lykke og ten in $i$ enotionelle erfaringer uden at lukke og uden at styrte dem ned i en patologisk overophidselse.

Alt dette indebærer en fundamental ændring af selve kunstbegrebet, hvis udgangspunkt kan være en refleksion over de kunstformer, som Hegel definerede som „symbolske“ (fra den egyptiske kunst til den jødiske og muslimske kunst uden billeder af det sublime). To tilsyneladende modsatrettede kritiske positioner kommer således til at mødes og blande sig. Den ene er rettet mod teknologiens mest avancerede udvikling, muligheden for teknisk at reproducere kunstværker, videoteknologien og elektronikken, mens den anden derimod er rettet mod erfaringens mest følelsesmæssige dimensioner, an-
tropologien og besiddelsen. Neo-eklekticismen og 
neo-romantikken er dybest set ikke andet end inadækvate formuleringer af disse kritiske tendenser, hvoraf den ene synes at betragte nutiden og den anden fortiden. I virkeligheden søger vi i videoteknologiens nutid en fortid af glæde og mangeartede erfaringer, mens vi i den antropologiske fortid søger en nutid af kopier og gentagelser. Den teknologiske og den antropologiske tendens fremstår med aspekter modsat of logiske tendens fremstar med aspekter moddaf, hyd de ste hilu futuristiske og Prometheus-agtige svulstigheder om verdensherredømme, og den anden er befriet for nostalgien efter oprindelse og autenticitet.

Sådan lader det sig forklare, at den første er lnyttet til en interesse for Tao og Zen, mens den anden, idet den har forladt oprindelsens purisme, er orienteret mod de aktuelle møder og krydsninger mellem de mest forskelligartede kulturer, ikke. så meget for at undersøge de sammenhængende og homogene systemers sammenbrud som for at følge de processer, der altid har bygget på podninger og kombinationer. På den ene side viser teknikkens essens sio altså som værende ikke-teknisk $0 \mathrm{p}$ den side viser det primit side viser det
ikke-primitivt.

\section{Kunst og museum}

Hvis nutidens kunst synes at have mistet sit traditionelle forhold til tiden, hvad er der så sket med dens forhold til rummet? Eksisterer der et forhold mellem kunstværket og stedet, hvor det befinder sig? Dette spørgsmål er dè sidste mange år blevèt besvaret med to modsatrettede teser. Den ene ser museet som det eneste sted, der trods mange begrænsninger og tvetydigheder er i stand til at garantere konservering og udstilling af kunstværkerne, mens den anden betoner nødvendigheden af et mere oprindeligt og essentielt forhold mellem disse of stedet, hyor og befinder sig. Den første tese er tæt forbundet med de sidste the ars asteiske refel fon skabe et æstetisk rum adskilt fra steder brugt til nytteaktiviteter, et rum bestemt til kontemplation. Som har disse karakteristika gjort museet til en verdslig fortsættelse af kirken eller templet og museets bes $\varnothing$ gende til troende i skønhedens religion. Denne tes måtte, tvunget af omstændighederne, begrænse sis til at interessere sig for museets mobile værker og altså udelukke arkitekturen og de værker der, som fresker, kun vanskeligt lader sig skille fra deres oprindelsessted. Men ved nærmere eftersyn blev disse udgransninger ikke set som betrennis disse dels foretive dels fom pga. dens tatte forbind dels fordi steder med fresker, glasruder eller store værker, der ikke lod sig transportere, normalt var kirker eller bygninger med nogenlunde samme vilkår som museets.

Den anden tese bebrejder museet, at det steriliserer kunstværket i et aseptisk rum og fjerner enhver grund til sand opmærksomhed og interesse for kunstværket. Ifølge denne tese garanterer museet kunstværkerne en overlevelse, der intet har at gore med deres egentlige liv. Denne position er uadkillelig fra den kritik som malere posion er ing anden har rettet mod for Ifølge dem har ethvert kunstværk sit eget rum, som det ikke kan adskilles fra, en sammenhæng hvortil det har sin livsstreng, hvad enten det er stedet, det er skabt til, kunstnerens atelier ellet et bestem miljø, som det har et intimt og kongenialt forhold til. De opfatter derfor ikke blot arkitekturen som mor til alle kunstarterne, men stræber efter at etablere et essentielt forhold mellem den og det landskab, den er anbragt i, og de ender med at påkalde en genius loci, en intim og oprindelig kvalitet ved stederne, som ethvert kunstværk må respektere og ikke bør adskilles fra.

Men er disse to teser stadig så radikale modsætninger, som det har forekommet deres respektive tilhængere? Det må det være tilladt at sætte spørgsmålstegn ved. På den ene side er museologien stadig mere orienteret mod inde $i$ museet at skabe kvalitativt homogene rum, hvor kunstværkerne kan anbringes' (som Chinese Garden Court i Metropolitan Museum i New York), eller at flytte hele ateliere eller ligefrem hele arkitektoniske værker ind $\mathrm{i}$ mu- seets rum for at fjerne dem fra en sikker ødelæggelse (som templet i Dendur). På den anden side er det ikke så få museer, der $i$ årenes løb har fảet en kunstnerisk aura tæt forbundet med det sted, hvor de er bygget, således at de selv bliver kunstværker og $\mathrm{ikk}$ blot beholdere for malerier og skulpturer.

Endelig har både museets og oprindelsesstedets tilhængere altid været enige om mindst én ting, nemlig at der eksisterer et eget sted for kunstværket, som det bør bevare et nært forhold til, og så er det i denne forbindelse mindre vigtigt, om det er museets æstetiske rum eller oprindelsesstedets kunstneriske rum. I begge tilfælde forudsætter man eksistensen af aurafyldte, højtidelige, hellige rum, som deres essens er intimt forbundet med kunstværkerne, og som samtidig behændigt er adskilt og fjernet fra alle de andre steder bestemt for økonomiske aktiviteter.

Det er netop denne forudsætning, som æstetikkens og kunstens udvikling har forladt. Der er såledens og hen salecleps skelsløs udstrolking af det astetiske rum og derfo tenderer mod et super-num, hur museets grænser i forhold til at tytte og udstille værkerne e overskredne. Og ved den modsatte pol er der opstået en anti-æstetik, der kæmper for en forskelslø udstrækning af det oprindelige rum og derfor tenderer mod et anti-museum, hvis opgave det er at vise, at ethvert sted, også og først og fremmest det mest dagligdags, kan have sin genius, sin kunstneriske kvalitet.

Hvis det traditionelle museum er skabt af værker, er super-museet skabt af billeder. Takket være fotografiet befrier denne retming kunstvarket for den begransing det er bun at vare et encelt sted

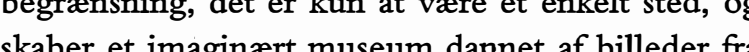

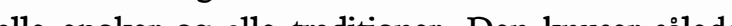
alle epoker og alle tadion. Den kasedes warkets enhed, idet den mangfoldiggor det 1 et uendeligt antal fragmentariske, fotografiske perspektiver, der overgar dets virkelige dimensioner. Det implicitte formål i museet som begreb, at forsone og harmonisere alle kunstværkerne og alle tendensern i det æstetiske rum, er her bragt til sin yderste konsekvens. I det super-æstetiske rum bliver alt dét forsonet og harmoniseret, som kan fotograferes elle filmes. Skønhedsreligionen bliver satellitagtig. Denne super-æstetik ledsages af en universalistis humanisme, som identificerer mennesket med tilskueren, med billednyderen.

Som super-museets modsatte pol opstår anti-muSom super-museets modsatte pol opstår anti-museet, gadens mert. Det setter sig ikke blor udd inde steder der udtryker en dybere kongen ater mellem de kunstneriske skaben og de sociale omgivelser. Antimuseet opløser, eller rettere dekonstruerer og destrukturerer kunstværket til den kreative aktivitet, hvoraf det er frembragt, og har til formål igen a sætte den oprindelige kreative proces, der har fundet sin afslutning i værket, i bevægelse. Det bringer således den kunstneriske revolte mod museet til sin yderste konsekvens, idet det gør oprindelsen og autenticiteten til den mest dagligdags virkelighed. Kunsten er overalt, hvor der eksisterer et socialt liv. Denne anti-rstetik ledsages af en humanisme, des peatter ethvert le humanisme, der opfat mmet til orde.

Men er super- og anti-æstetikken virkelig så radikale modsætninger, som det forekommer deres tilhængere? Det må det være tilladt at sætte spørgsmålstegn ved. På den ene side implicerer super-museet eksistensen af et marked for kunstbøger, der e så stort, at det ikke blot kan baseres på det lille antal connaisseurs, men forudsætter en bred interesse for kunstens liv, fx blandt de besøgende til de store udstillinger. På den anden side fremmer antimuseet, netop pga. sin forbigående og antiinstitutionelle karakter, fotografiske og cinematografiske billedindslag, som kun kan konservere og dokumentere det, der sker på gaden. Billedet og gaden viser sig at

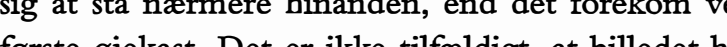
forte opnat en relame og propagandamæssig betydning, der ogsà har pàvirket kunsten. Kulturpolitisk er det, der betyder noget, ikke længere forholde mellem kunstværket og fotografiet af det, men hvilket offentligt billede kunsten formår at give af sig selv. Omvendt minder det dagligdags liv stadig mere om en videooptagelse, og det $\mathrm{i}$ en sådan grad at spejlmetaforen for nogle synes mere velegnet til at 
beskrive hverdagen end henvisninger til autentiske og oprindeligt gjorte erfaringer.

Super-museet og anti-museet, super-æstetikken og anti-æstetikken arver to modsatrettede forestillinger om kunst, men hverken den ene eller den an den spørger sig selv, om der i denne forskelsløse udstrakning af hy. det astetiske og det kreative udstrækang af hlv. det asteriske og det leative rum sher noget mere afgorth

\section{Den barokke effekt: samlingens gåde}

Hvis det nye forhold mellem kunst og tid opløse kunsthistorien og skaber en egyptisk effekt, så opleser det nye forhold mellem kunst og rum museet og skaber en barok effekt. Denne er tæt forbundet me den egyptiske effekt, fordi den er en folge af den tingslige dimension, som kunstværket har påtaget sig. Siden r70o-tallet har æstetikken og overvejelserne over kunsten vænnet os til at opfatte kunstværkerne som ting af en særlig art $i \mathrm{kraft}$ af, at tilhørte en højere, mere indelig og autonom at end andre ting. De var lidt mindre "tin"“ end andre ing. De var and ligdagens brugbare objekt. Den egyptiske effel far os dencinod til at se den som mere del af "tingsligheden "end de dagligdags ting. Den hævder det "tingsliges" førerstilling i forhold til det subjektiv og det ideelle. Den fascination som den egyptisk kultur udøvede i r6oo-tallet, hvor Athanasius Kichers værk Oedipus Aegyptiacus er det mest kendte og overraskende udtryk, skyldes netop den symbolske udvendighed i en kunst, der ikke overstiger, men konkurrerer med naturen

Heraf:kan udledes nogle usædvanlige følger. Ved første blik formindskes den afstand, som den moderne æstetik har sat mellem kunst og ikke-kunst. museet søger man ikke mere ånden eller subjektet, museet soger mas ike men en en særlig type kulturgode. Ud af 150 museer i New York er mindre end halvdelen kunstmuseer. De ovrige er samlinger af de mest forskelligartede objekter ud fra en interesse, der kan være historisk videnskabelig, biologisk, social.... De zoologiske haver, de botaniske haver, bibliotekerne, monumenterne, berømte menneskers huse og endda fænglerne (med Alcatraz som forbillede) er ved at opnà en status, der ikke er væsensforskellig fra kunstgalleriernes. Samtidig rammer de kunstneriske samlinger alligevel en mere gådefuld dimension ved fortiden, fordi man ikke forstår hvilke kriterier, der ligger til grund for udvælgelsen.

De såkaldte kunstnermuseer", dvs, de private Ding samlinger af mærkværige ting, der minder om de barker og er samlet og bevar af nuleve knstrere, er allerede en del af kulturgodernes logik. Kunstnerens samling af ting er ikke egentlige, sande kunstværker og heller ikke ready-mades, men objekter der har fâet tillagt en kulturel betydning, ganske enkelt fordi de er blevet udvalgt og bevaret af kunstneren. Anderledes er det ikke med den tendens, hvor nogle museumsdirektører tildeler sig selv en rolle, der er vigtigere end kunstnerens. Den er, selvom fremgangsmåden kan være en åbenlys vildfarelse, en del af samlingens logik. De er ikke længere kustoder for kunstrorkerne, for resultateme af andres leeativitet, men skabere af samlinger. men skabere af samlinger.
I samlingen bliver rummet autonomt og opnår en baseret på forestillingen om rummet som beholder, og oprindelsesstedet var baseret pa forestillingen om rummet som en betingelse for sameksistens, introducerer samlingen forestillingen om rummet som felt. Det felt, som samlingen åbner, er summen af de betingelser, der gør det muligt at transformere et objekt til et kulturgode. Det, der bestemmer et kulturgode som sådant, er, at det befinder sig i feltet. Uden for dette rum ville objektet være af langt mindre interesse. Man genfremsætter således barokkens idé om samlingen, forstået som en samling af objekter tæt lnyttet til en teoretisk forskning.

Over for denne nye kulturelle praksis baseret på Over for denne nye kulturelle praksis baseret på samling sig i vanskeligheder. Den har faktisk indtil nu - også i super- og anti-museet - baseret sig på en forestilling om kunsten, der gav det enkelte objekt og den enkelte kunstneriske erfaring en indre værdi, uafhængigt af hvilken rumlige situation det befandt sig i. Overgangen fra et strengt og fast system af referencer, der bygger på det enkelte kunstværks værdi eller på kunstnerens person, til et system af re- lative rumlige og sociale koordinater viser sig meget vanskelig. Den æstetiske smag hos museumsdirektoren, der vælger de „smukkeste“ værker, eller de enkelte kunstners genialitet garanterer ikke i sig selv åbningen af et felt. Smag og genialitet, disse to fundamentale begreber $i$ r700-tallets æstetik, er p̊̊ den ene side for dogmatiske og på den anden side for ti faldige. faldige. S kunsten ilke me is teoretisk fundament for en kategorisering af de kunstneriske objekter. Eftersom der lkke længere eksisterer et tæt, indre samhørighedsforhold mellem kunst og historie, er den historiske overvejelse blevet rent kronologisk. Forsøgene med en kunstens geografi kan heller ikke give mere overbevisende resultate Transmissioner og blandinger af kulturerne formindsker eller ophæver faktisk i visse tilfælde helt betydningen af lokale og nationale traditioner.

Der er nogle, der mener, at ikonologien, fordi den flytter opmærksomheden mod kunstværkerne indhold, kan vise en vej ud af disse problemer. indhold, knoblemer. De kunne skabe en ence dennes forskellige dele havde det sanme indhold. Men problemet bliver mact begynder at spørge, hvad vi forstår ved indhold: $\mathrm{E}$ det det kunstheriske motiv, dvs. det primære og naturlige indhold som $\mathrm{fx}$ en menneskekrop, eller det kulturelle tema, dvs. det sekundære og konventionelle indhold som $\mathrm{fx}$ en eller anden bibelsk elle mytologisk figur, eller måske den indre betydning, dvs. den symbolske værdi, der er kunstværkets dybere mening? Hver enkelt af disse tre dimensioner kan danne grundlag for en sammenhæng i samlingen, men intet kan tages for givet. Det synes derfor, som om der $i$ samlingens eksistensbertiselse in, som om der i sank anserettigelse indeholdt et teoretisk arbede, som má gøres $i$ hvert enkelt ilfelde, og som skaber og ledsager den. Kutning bliver således uadskillelige.

Det er klart, at man over for disse vanskeligheder nogle gange vil vælge den letteste vej, nemlig at give afkald på samlingen, at benægte feltet som et nyt sted for kunsten og at transformere det enkelte kunstværk $i$ en vandrende skat, der kan udstilles overalt. Inden for denne begrebshorisont bliver kunstværket til noget absolut, og alle dets forbindelseslinjer til tid og rum, til historie og geografi, til sin egen skaber og til andre kunstværker er skăret over. Hvad der betyder noget, er dets rene identitet. Kun for denne og ikke for dets gådefulde overgange fortjener det at blive bevaret og udstillet. Den teoretiske refleksion, der soger at skabe et net af relationer rundt om lunstverket, er brutalt shot midt

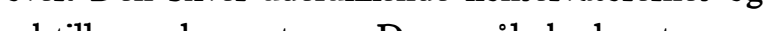

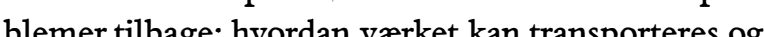
opherares og at lide skade, og hvordan det kan blive set af det storst mulige antal personer.

Men allerede nu er næsten alle objekter modtagelige for at blive isolerede og gjort til skatte. Forureningen $i$ atmosfæren og $i$ byerne bringer hele historiske bykerner i fare, som det sker i Rom. De miljømæssige forringelser gør, at antallet af truede objekter, plante- og dyrearter vokser enormt. Hele verden er $i$ fare for at blive en organisme på vej mod ødelæggelse og for at identificere sig med museet om sig selv.

Naturligvis genskaber denne situation inden dødskampen en forbindelse mellem objekterne. Hvis alt er truet, er alt værdigt til at blive indsamlet: fra industrimaskiner, der er blevet overhalet af den teknologiske udvikling til gammelt husgeråd, fra kriminalmuseernes forbryderværktøj til tilsynekomster fra det hinsides (som i det utrolige museum i Rom for ,sjæle fra helvede“). Udsigten til enden ledsages af en feber, der forstørrer antallet af samlinger i det uendelige, idet den følger en logik, som ikke er overgangens og gådens, men tværtimod identitetens og banalitetens.

Skattens og katastrofens æstetik udelukker muligheden for et felt of ting for en samling. Den forste adskiller objektet fra alle de ovige, den anden ble der det sangen med dem. Nudens medation over det estetiske skal imidlertid gå i den modsatte retning og finde tværgående forbindelser, hvor skattens æastetik ser enestående stykker, og omvendt understrege forskelle, hvor katastrofens æstetik ser ligheder. Den skal arbejde gennem overgange og 
rokeringer, der åbner nye rum og skaber nye betydninger.

Den aktuelle erfaring med mennesker, der fylder museerne i massevis, kræver en radikal genovervejelse af de samme fundamentale forestillinger, som er baggrund for samlingen, altså konserveringen udstillingen of ting. To faktorer fortiener opmerksom. For det foste ment markon tendens til afe mo dukioneme (poskont, forograter, plakater...) udstillede i museets boghandel end pa onginalerne udstillede i salene. Til grund for denne holding, som er en vildfarelse for enhver connaisseur, ligger ikke, at billedet foretrækkes for originalen, men ønsket om at købe, at tage med hjem, at samle tingene selv. For det andet er det, der trækker folk til de store museer, ikke så meget ønsket om at se det udstillede, men det faktum, at store mængder allerede har set det og vil se det. Motoren i denne opførsel, der for kunstelskere ikke er mindre vildfaren end den forste, er dog ilke viljen til at deltage $i$ en kollehtiv, korligende vision, men anset om ilke at vare kellign figer stiger mikrom

Det første fænomen kan ikke forklares ud fra et begreb om billedet, sådan som super-æstetikken ville gøre det, og det andet kan ikke forklares ud fra et begreb om den sociale deltagelse, sådan som antiæstetikken ville gøre det. Disse begreber viser sig, også i deres perfektionering og udvikling, helt ude af stand til at gribe det mærkelige, gåden, den barokke dimension ved den aktuelle situation.

En samling er hverken skabt af enestående værker uden indbyrdes forbindelse eller af billeder, men af ing. Den tiltrolong som den udover, a fhenger af om den mellem ing son diaber et net a relationer, or tilskeren ilke kan lukkes ude. Besiddersen en reproduktion, et katalog, en video tilfredsstille dette krav på en måde, der er latterlig, men i omfang er større end det blot at se objektet.

Det område, der åbnes med en samling, er hverken den offentlige, veluddannede opinion eller den sociale deltagelse, men et rum der tiltrolker os poto fordi det Den mulighed for memberhip, som nog Dilby dich latterlig, men i omfang er støre end det at læse avienes onte af udstillngeme. Samlingens gåde lader sig ikke adskille fra samfundets gåd.

\section{På dansk ved Birgit Eriksson}

Oversat fra kapitlet „Arte, tempo e spazio“, s. 82-99 i Mario Perniola: Enigmi. Il momento egizio nell società e nell'arte. Genova: Costa \& Nolan 1990.

Litteratur

Theodor W. Adorno: „Valéry, Proust Museum“, in Prismen, Frankfurt am Main I95s.

(Pere Bourdieu: L'amour de l'art. Les musées et leur public, Paris 1966.

Remo Guidieri: „L'imaginaire du musée“, in Res nr. 9, Cambridge (USA) r985.

Arnold George Kubler: The shape of time: Remarks on the history of

政 Robert Lumley (red). L Venedig 1986.

. Lindustria del museo, Genova 1989. Jean François - Marquet: „,La quête isiaque de Athanasius Wrcher , in Les etudes philosophiques $\mathrm{nr}$. 2-3, 1987.

Andre Malani, Le

, in La filosofia prima dei Greci, Torino 1963.

Wölfflin: Kunstgeschichtliche Grundbegriffe: dos der Stilentwicklung in der neueren Kunst, München 